\title{
INTELLECTUAL EFFICIENCY IN RELATION TO INSANITY.
}

By A. J. ROSANOFF, M. D.,

Kings Park State Hospital, Kings Park, N. Y.

New points of view, created by recent advances of the science of eugenics, suggest the need of a reinvestigation of questions which formerly seemed to possess but a theoretical interest. As far as eugenics is concerned with insanity, the general and paramount issue is, of course: To what extent are the forms and varieties of inheritable neuropathic conditions antisocial in their manifestations? But the antisocial quality itself may depend in one case on intellectual defects, in another on temperamental ones, in a third on moral ones-each case obviously constituting a special problem.

As regards intellectual efficiency, the view that is perhaps most commonly held is that in insane persons it is more or less generally and markedly below par; and although the occurrence even of genius in connection with insanity is admitted, yet we often hear such genius characterized as but a one-sided overdevelopment with none the less apparent general defect. Whether this view is wholly correct, or whether it requires some qualification, it is the object of this study to determine; at any rate it is hoped that the material presented may be of interest to those concerned with the problem.

The question of the relationship between genius and insanity is a very old one, as all know; and although most diverse views have been held concerning the nature of this relationship, it is admitted on all sides that abnormal mental manifestations frequently occur in persons of great mental endowment. In connection with our inquiry this fact alone can afford no definite conclusions: that a small group of individuals, occupying biologically a position separated as widely as possible from the average, have been found to differ from the average also in 
ailments of the nervous apparatus or in susceptibility to such ailments, is in itself a circumstance far from sufficient to establish any sort of relationship between genius and insanity, speaking of the latter as it comes to our observation in the shape of ordinary clinical material. We are here especially concerned with the questions: Are there any instances of intellectual efficiency of very high order to be found in persons who have also presented fully developed neuropathic manifestations definitely assignable to one or another of the better known clinical groups? If so, is the relationship between the extraordinary mental efficiency of these subjects and their neuropathic constitution essential or merely incidental?

It is to be observed, to begin with, that very little material is available that might aid in finding answers to these questions. The biographies of most great men are far too incomplete, at least from the psychiatric standpoint. Turning to the cases in which we are able to gain some real insight into the psychic constitution, we find, for the most part, only evidences of slight, vague, atypical, fleeting ailments, to which special significance could be attributed only by reference to arbitrary and practically non-existent standards of mental health. Finally, as we come to cases presenting acceptable evidences of mental or nervous disease, we find them not infrequently to be but cases of general paresis, tabes, or other essentially exogenous disorders, and not of inborn neuropathic conditions.

However, cases are to be found-though it is but by way of exception-in which well-marked neuropathic manifestations have existed, quite sufficient to establish a clinical diagnosis beyond question. Among the clearest seem to be the cases of William Cowper, Julius Robert Mayer, and Gustave Flaubert.

\section{(A) The Case of William Cowper.}

William Cowper was born in 1731. Even in his childhood it was noted that he was of a nervous temperament; but at the age of 2I he developed the first evidences of mental trouble which, from the symptoms as subsequently described by himself, from the course, and from the fact that it was later followed in characteristic fashion by repeated recurrences, may readily be judged 
AMERICAN JOURNAL OF INSANITY, VOL. LXXIII, No. 1. PLATE I.

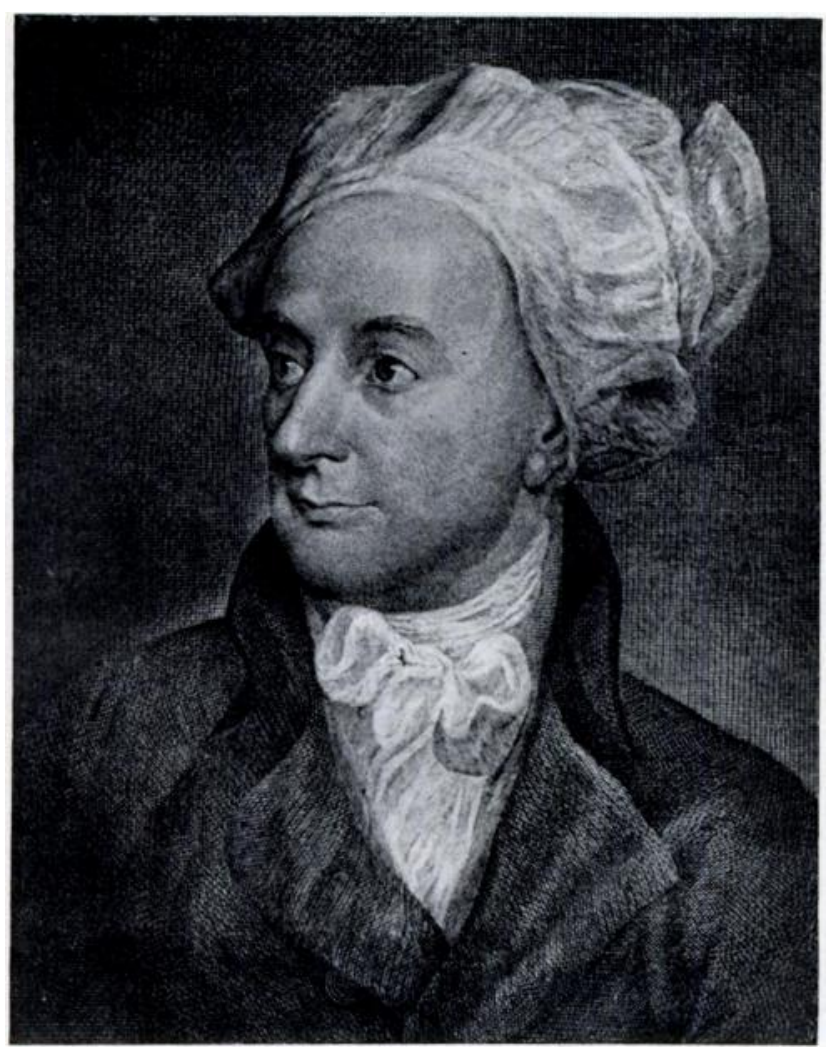

WILLIAM COWPER. 
to have been an attack of manic-depressive insanity. To quote from his own memoirs: ${ }^{1}$

I was struck, not long after my settlement in the Temple, with such a dejection of spirits, as none but they who have felt the same can have the least conception of. Day and night I was upon the rack, lying down in horror, and rising in despair. I presently lost all relish for those studies to which I had before been closely attached; the classics had no longer any charms for me; I had need of something more salutary than amusement, but I had no one to direct me where to find it.

In this state of mind I continued nearly twelve months.

A change of scene was recommended to me, and I embraced an opportunity of going with some friends to Southampton, where I spent several months. Soon after our arrival, we walked to a place called Freemantle, about a mile from the town; the morning was clear and calm; the sun shone bright upon the sea; and the country on the borders of it was the most beautiful I had ever seen. We sat down upon an eminence, and at the head of that arm of the sea, which runs between Southampton and the New Forest. Here it was that on a sudden, as if another sun had been kindled that instant in the heavens, on purpose to dispel sorrow and vexation of spirit, I felt the weight of all my misery taken off ; my heart became light and joyful in a moment; I could have wept with transport had I been alone.

The second attack occurred eleven years later, and was far more protracted and severe. We will quote again from his own description :

The feelings of a man, when he arrives at the place of execution, are probably much like mine, every time I set my foot in the office, which was every day, for more than half a year together.

Now came the grand temptation; the point to which Satan had all the while been drawing me; the dark and hellish purpose of self-murder. I grew more sullen and reserved, fled from all society, even from my most intimate friends, and shut myself up in my chambers. The ruin of my fortune, the contempt of my relations and acquaintance, the prejudice I should cause my patron, were all urged on me with irresistible energy. Being reconciled to the apprehension of madness, I began to be reconciled to the apprehension of death. Though formerly, in my happiest hours, I had never been able to glance a single thought that way without shuddering at the idea of dissolution, I now wished for it, and found myself but little shocked at the idea of procuring it myself. Perhaps, thought $I$, there is no God; or if there be, the Scriptures may be false; if so, then God has nowhere forbidden suicide. I considered life as my property, and therefore at my own disposal. Men of great name, I observed. had destroyed themselves; and the world still retained the profoundest respect for their memories. 
But above all I was persuaded to believe, that if the act were ever so unlawful, and even supposing Christianity to be true, my misery in hell itself would be more supportable.

One evening in November, 1763 , as soon as it was dark, affecting as cheerful and unconcerned an air as possible, I went into an apothecary's shop and asked for a half ounce phial of laudanum. . . . . Distracted between the desire of death and the dread of it, twenty times I had the phial to my mouth, and as often received an irrestible check. . . . I I spent the rest of the day in a kind of stupid insensibility; undetermined as to the manner of dying, but still bent on self-murder, as the only possible deliverance. . . . . I went to bed to take, as I thought, my last sleep in this world. The next morning was to place me at the bar of the house, and I determined not to see it. I slept as usual, and awoke about three o'clock. Immediately $I$ arose, and by the help of a rushlight, found my penknife, took it into bed with me, and lay with it for some hours directly pointed against my heart. Twice or thrice I placed it upright under my left breast, leaning my weight upon it; but the point was broken off square, and it would not penetrate.

In this manner the time passed till the day began to break. I heard the clock strike seven, and instantly it occurred to me, there was no time to be lost: the chambers would soon be opened, and my friend would call upon me to take me with him to Westminster. "Now is the time," I thought; "this is the crisis; no more dallying with the love of life!"

Not one hesitating thought now remained, but I fell greedily to the execution of my purpose. My garter was made of a broad piece of scarlet binding, with a sliding buckle, being sewn together at the ends: by the help of the buckle, I formed a noose, and fixed it about my neck, straining it so tight that I hardly left a passage for my breath, or for the blood to circulate; the tongue of the buckle held it fast.

I set the door open, which reached within a foot of the ceiling; by the help of a chair I could command the top of it, and the loop being large enough to admit a large angle of the door, was easily fixed so as not to slip off again. I pushed away the chair with my feet, and hung at my whole length. While I hung there, I distinctly heard a voice say three times, "Tis over!" Though I am sure of the fact, and was so at the time, yet it did not at all alarm me, or affect my resolution. I hung so long that I lost all sense, all consciousness of existence.

When I came to myself again, I thought myself in hell; the sound of my own dreadful groans was all that I heard, and a feeling, like that produced by a flash of lightning, just beginning to seize upon me, passed over my whole body. In a few seconds I found myself fallen on my face to the floor. In about half a minute I recovered my feet; and reeling, and staggering, stumbled into bed again.

By the blessed providence of God, the garter which had held me till the bitterness of temporal death was past, broke just before eternal death had taken place upon me. 
To this moment I had felt no concern of a spiritual kind. . . . . Now, therefore, a new scene opened upon me. Conviction of sin took place, especially of that just committed; the meanness of it, as well as its atrocity, was exhibited to me in colors so inconceivably strong, that I despised myself, with a contempt not to be imagined or expressed, for having attempted it. This sense of it secured me from a repetition of a crime, which I could not now reflect on without abhorrence.

My sins were now set in array before me. I began to see and feel that I had lived without God in the world. As I walked to and fro in my chamber, I said within myself, "There never was so abandoned a wretch ; so great a sinner."

In every book I opened, I found something that struck me to the heart. I remember taking up a volume of Beaumont and Fletcher, which lay upon the table in my kinsman's lodgings, and the first sentence which I saw was this: "The justice of the gods is in it." My heart instantly replied, "It is of truth," and I cannot but observe, that as I found something in every book to condemn me, so it was the first sentence, in general, I pitched upon. Everything preached to me, and everything preached the curse of the law.

I never went into the street, but I thought the people stared and laughed at me, and held me in contempt; and I could hardly persuade myself, but that the voice of my conscience was loud enough for every one to hear it. They who knew me seemed to avoid me! and if they spoke to me they seemed to do it in scorn. I bought a ballad of one who was singing in the street, because $I$ thought it was written on me.

The capital engine in all the artillery of Satan had not yet been employed against me. Already overwhelmed with despair, I was not yet sunk into the bottom of the gulf. This was a fit season for the use of it; accordingly I was set to inquire, whether I had not been guilty of the unpardonable sin; and was presently persuaded that I had.

My thoughts in the day became still more gloomy, and my night visions more dreadful. One morning, as I lay between sleeping and waking, I seemed to myself to be walking in Westminster Abbey, waiting till prayers should begin; presently I thought I heard the minister's voice, and hastened towards the choir; just as I was upon the point of entering, the iron gate under the organ was flung in my face, with a jar that made the abbey ring; the noise awoke me! and a sentence of excommunication from all the churches upon earth could not have been so dreadful to me, as the interpretation which I could not avoid putting upon this dream.

I felt a sense of burning in my heart, like that of real fire, and concluded it was an earnest of those eternal flames which would soon receive me. I laid myself down, howling with horror, while my knees smote against each other.

In this condition my brother found me, and the first words I spoke to him were, "Oh! brother, I am damned! think of eternity, and then think what it is to be damned!" I had, indeed, a sense of eternity impressed 
upon my mind, which seemed almost to amount to a full comprehension of it. My brother, pierced to the heart with the sight of my misery, tried to comfort me; but all to no purpose. I refused comfort; and my mind appeared to me in such colors, that to administer it to me, was only to exasperate me, and to mock my fears.

At eleven o'clock my brother called upon me, and in about an hour after his arrival, that distemper of mind, which I had so ardently wished for, actually seized me.

While I traversed the apartment, in the most horrible dismay of soul, expecting every moment that the earth would open her mouth and swallow me; my conscience scaring me, the avenger of blood pursuing me, and the city of refuge out of reach and out of sight; a strange and horrible darkness fell upon me. If it were possible that a heavy blow could light on the brain, without touching the skull, such was the sensation I felt. I clapped my hand to my forehead, and cried aloud, through the pain it gave me. At every stroke my thoughts and expressions became more wild and indistinct; all that remained clear was the sense of sin, and the expectation of punishment. These kept undisturbed possession all through my illness, without interruption or abatement.

My brother instantly perceived the change, and consulted with my friends on the best manner to dispose of me. It was agreed among them, that I should be carried to St. Alban's, where Dr. Cotton kept a house for the reception of such patients, and with whom I was known to have a slight acquaintance. Not only his skill, as a physician, recommended him to their choice, but his well-known humanity and sweetness of temper. It will be proper to draw a veil over the secrets of my prison-house.

About eight months after Cowper was taken to the private sanatorium a marked improvement was noted in his mental condition, and shortly after a sudden change to elation, which lasted but a brief period preceding full recovery. His description of this elation is, if anything, even more significant than that of the other phase of his attack.

The servant observed a sudden alteration in me for the better; and the man, whom I have ever since retained in my service, expressed great joy on the occasion.

I went to bed and slept well. In the morning I dreamed that the sweetest boy I ever saw came dancing up to my bedside; he seemed just out of leading strings, yet I took particular notice of the firmness and steadiness of his tread. The sight affected me with pleasure, and served at least to harmonize my spirits; so that I awoke for the first time with a sensation of delight on my mind. Still, however, I knew not where to look for the establishment of the comfort I felt. My joy was as much a mystery to myself as to those about me. 
My physician, ever watchful and apprehensive for my welfare, was now alarmed, lest the sudden transition from despair to joy should terminate in fatal frenzy. But "the Lord was my strength and my song, and was become my salvation"..... In a short time Dr. C. became satisfied, and acquiesced in the soundness of my cure.

Cowper's third attack developed gradually about nine years later, that is, in the latter part of 1772 . Years later he wrote a description of it from memory in a letter to Lady Hesketh, from which we quote:

In the year 1773, the same scene that was acted at St. Alban's opened upon me again at Olney, only covered with a still deeper shade of melancholy, and ordained to be of much longer duration. I was suddenly reduced from my wonted rate of understanding, to an almost childish imbecility. I did not, indeed, lose my senses, but I lost the power to exercise them. I could return a rational answer, even to a difficult question; but a question was necessary, or I never spoke at all. This state of mind was accompanied, as I suppose it to be in most instances of the kind, with misapprehensions of things and persons, that made me a very untractable patient. I believed that everybody hated me, and that Mrs. Unwin hated me most of all-was convinced that all my food was poisoned, together with ten thousand megrims of the same stamp. I would not be more circumstantial than is necessary. Dr. Cotton was consulted. He replied, that he could do no more for me than might be done at Olney, but recommended particular vigilance, lest I should attempt my life-a caution for which there was the greatest occasion. At the same time that I was convinced of Mrs. Unwin's aversion to me, I could endure no other companion. The whole management of me consequently devolved upon her, and a terrible task she had. She performed it, however, with a cheerfulness hardly ever equalled on such an occasion; and I have often heard her say, that if ever she praised God in her life, it was when she found that she was to have all the labor.

The fourth attack occurred in 1787 , that is, after an interval of I4 years. His depression again led to an attempt at suicide by hanging, and this time he would have succeeded had he not been cut down just in time by Mrs. Unwin, who happened to enter the room. The beginning of this attack is foreshadowed in a letter to $\mathrm{Mr}$. Newton under date of January I3, 1787, from which we quote:

It may seem strange, but is true, that after having written a volume, in general with great ease to myself, I found it impossible to write another page. The mind of man is not a fountain but a cistern; and mine, God knows, a broken one. .... A whole year I waited and waited in circum- 
stances of mind that made a state of non-employment peculiarly irksome to me. I longed for the pen, as the only remedy, but I could find no subject: extreme distress of spirit at last drove me, as, if I mistake not, I told you some time since, to lay Homer before me, and translate for amusement.

In a letter written in October of the same year, evidently on recovery, there is some reference to the attack itself, which, it seems, is the only one to be found anywhere. We quote again:

$\mathrm{My}$ indisposition could not be of a worse kind. The sight of any face, except Mrs. Unwin's, was to me an insupportable grievance; and when it has happened that by forcing himself into my hiding-place, some friend has found me out, he has had no great cause to exult in his success. From this dreadful condition of mind, I emerged suddenly, so suddenly, that Mrs. Unwin, having no notice of such change herself, could give none to anybody; and when it obtained, how long it might last, or how far it might be depended on, was a matter of the greatest uncertainty.

The fifth, and last, distinct attack developed in the early part of I794 and lasted over three years, if, indeed, it is possible to say at all that it ended in recovery. Brief accounts of it are to be found in the letters of some of Cowper's friends. The following quotation is from a letter written by $\mathrm{Mr}$. Greathead to William Hayley, dated April 8, 1794 :

Lady Hesketh's correspondence acquainted you with the melancholy relapse of our dear friend at Weston, but I am uncertain whether you know, that in the last fortnight he has refused food of every kind, except now and then a very small piece of toasted bread, dipped generally in water, sometimes mixed with a little wine.

In a letter dated May 5, I795, addressed to Mr. Johnson, Lady Hesketh writes:

But it grieves me to say he is very bad indeed-scarce eats anything!is worn to a shadow! and has totally given up all his little avocations, such as netting, putting maps together, playing with the solitary board, etc., etc., with which we contrived to while away the winter more tolerably than I had any reason to expect. He now does nothing but walk incessantly backwards and forwards, either in his study or his bed-chamber. He really does not simetimes sit down for more than half an hour the whole day, except at meal times, when, as I before said, he takes hardly anything. He has left off bathing his feet, will take no laudanum, and lives in a constant state of terror that is dreadful to behold! He is now come to expect daily, and even hourly, that he shall be carried away; and kept in his room from the time breakfast was over till four o'clock on Sunday last, 
in spite of repeated messages from Madame (Mrs. Unwin), because he was afraid somebody would take possession of his bed, and prevent his lying down on it any more!

Aside from distinct attacks Cowper was in general of a sad temperament, such as is characteristic of many cases of manicdepressive insanity. Thus, in a letter, part of which has already been quoted, addressed to Lady Hesketh under date of January 16, 1786, the poet himself describes his condition during the comparatively normal interval which followed the illness of 1773 :

It will be 13 years, in a little more than a week, since this malady seized me. Methinks I hear you ask-your affection for me will, I know, make you wish to do so- "Is it removed?" I reply, in great measure but not quite. Occasionally I am much distressed, but that distress becomes gradually less frequent, and, I think, less violent. I find writing, and especially poetry, my best remedy. Perhaps had I understood music, I had never written verse, but had lived upon fiddle-strings instead. It is better, however, as it is. A poet may, if he pleases, be of a little use in the world, while a musician, the most skillful, can only divert himself and a few others. . . . . In the year when I wrote the Task (for it occupied me about a year), I was very often most supremely unhappy; and am, under God, indebted in a good part to that work for not having been much worse.

In another letter, which has also already been quoted in part, the one to Mr. Newton, dated January 13, 1787, we find the following :

As to fame, and honor, and glory, that may be acquired by poetical feats of any sort, God knows, that if I could lay me down in my grave with hope at my side, or sit with hope at my side in a dungeon all the residue of my days, I would cheerfully waive them all. For the little fame that I have already earned has never saved me from one distressing night, or from one despairing day, since I first acquired it.

Towards the last years of his life Cowper frequently experienced auditory hallucinations which occurred generally in the morning just before his waking; it is remarkable that he credited these with oracular significance. Some of the hallucinations and the conditions under which they occurred are to be found described in a series of letters written, for the most part, to $\mathrm{Mr}$. Teedon during 1792: "The ear of the Lord is open to them that fear Him, and He will hear their cry." "Fulfil thy promise to me." "Apply assistance in my case, indigent and necessitous." "It will not be by common and ordinary means." "Meantime raise an expectation and desire of it among the people." 
At least in one instance Cowper's interpretation of his hallucination as a warning of impending disaster was subsequently proved correct:

My nights are almost all haunted with notices of great affliction at hand, of what kind I know not; but in degree, such as I shall with extreme difficulty sustain, and hardly at last find deliverance. At four this morning I started out of a dream, in which I seemed sitting before the fire, and very close to it, in great trouble; with suddenly stamping violently with my foot, and springing suddenly from my seat, I awoke, and heard these words, "I hope the Lord will carry me through it." This needs no interpretation. It is plainly a forewarning of woe to come; and though you may tell me I ought to take comfort from the hope expressed in the words, yet truly I cannot. (December I4, 1792.)

But a short time afterwards, as already stated, the last and most distressing attack of his life began.

It would seem, then, that the fact of William Cowper having been a sufferer from manic-depressive insanity is not to be questioned. It may now be asked, Was there any essential connection between his insanity and his poetical productions? He himself always maintained that even his most humorous writings were the more or less direct results of his moods of sadness, paradoxical as it may seem:

If I trifle, and merely trifle, it is because I am reduced to it by necessity; a melancholy that nothing else so effectually disperses, engages me sometimes in the arduous task of being merry by force. And, strange, as it may seem, the most ludicrous lines I ever wrote have been written in the saddest mood, and but for the saddest mood, perhaps, had never been written at all.

It is interesting to note that this was written with special reference to no other poem than John Gilpin.

Among the works of Cowper it is not difficult to find some which, though of surpassing beauty and power, are nevertheless undoubtedly the products of morbid moods. The following, for instance, was written in the latter part of 1763 , during the time between his suicidal attempt and his removal to the private asylum at St. Alban's :

Hatred and vengeance-my eternal portion Scarce can endure delay of executionWait with impatient readiness to seize my

Soul in a moment. 
Damn'd below Judas; more abhorr'd than he was, Who for a few pence sold his holy Master!

Twice betray'd Jesus me, the last delinquent,

Deems the profanest.

Man disavows, and Deity disowns me,

Hell might afford my miseries a shelter;

Therefore, Hell keeps her ever hungry mouth all

Bolted against me.

Hard lot! encompassed with a thousand dangers,

Weary, faint, trembling with a thousand terrors,

I'm call'd, if vanquish'd! to receive a sentence

Worse than Abiram's.

Him the vindictive rod of angry Justice

Sent quick and howling to the center headlong;

$\mathrm{I}$, fed with judgment, in a fleshy tomb, am

Buried above ground.

Hardly less striking, from a psycho-pathological standpoint, is the poem written during a brief period of elation while still at the asylum at St. Alban's :

\section{THE HAPPY CHANGE.}

How bless'd Thy creature is, O. God, When with a single eye,

He views the luster of Thy Word, The dayspring from on high!

Through all the storms that veil the skies And frown on earthly things,

The Sun of Righteousness he eyes, With healing on His wings.

Struck by that light, the human heart, A barren soil no more,

Sends the sweet smell of grace abroad, Where serpents lurk'd before.

The soul, a dreary province once Of Satan's dark domain,

Feels a new empire form'd within, And owns a heavenly reign. 
The glorious orb whose golden beams

The fruitful year control,

Since first obedient to Thy Word,

He started from the goal,

Has cheer'd the nations with the joys

His orient rays impart;

But, Jesus, 'tis Thy light alone

Can shine upon the heart.

Finally, in this connection, we would cite the last original poem written by Cowper:

THE CASTAWAY.

Obscurest night involved the sky,

The Atlantic billows roar'd,

When such a destin'd wretch as I,

Wash'd headlong from on board,

Of friends, of hope, of all bereft,

His floating home forever left.

No braver chief could Albion boast

Than he with whom he went,

Nor ever ship left Albion's coast

With warmer wishes sent.

He loved them both, but both in vain;

Nor him beheld, nor her again.

Not long beneath the whelming brine Expert to swim, he lay;

Nor soon he felt his strength decline, Or courage die away;

But waged with death a lasting strife,

Supported by despair of life.

He shouted; nor his friends had fail'd

To check the vessel's course,

But so the furious blast prevail'd,

That pitiless perforce

They left, their outcast mate behind,

And scudded still before the wind.

Some succor yet they could afford;

And, such as storms allow,

The cask, the coop, the floated cord, Delay'd not to bestow :

But he, they knew, nor ship nor shore,

Whate'er they gave, should visit more. 
Nor, cruel as it seem'd, could he Their haste himself condemn,

Aware that flight, in such a sea, Alone could rescue them;

Yet bitter felt it still to die

Deserted, and his friends so nigh.

He long survives, who lives on hour In ocean, self-upheld :

And so long he, with unspent power, His destiny repell'd;

And ever, as the minutes flew,

Entreated help, or cried-“Adieu!"

At length, his transient respite past, His comrades, who before

Had heard his voice in every blast, Could catch the sound no more :

For then, by toil subdued, he drank

The stifling wave, and then he sank.

No poet wept him; but the page Of narrative sincere,

That tells his name, his worth, his age, Is wet with Anson's tear:

And tears by bards or heroes shed

Alike immortalize the dead.

I therefore purpose not, or dream, Descanting on his fate,

To give the melancholy theme

A more enduring date :

But misery still delights to trace

Its semblance in another's case.

No voice divine the storm allay'd,

No light propitious shone,

When, snatch'd from all effectual aid,

We perish'd, each alone:

But I beneath a rougher sea,

And whelm'd in deeper gulfs than he.

It may be safely said, it seems to us, that had not Cowper been insane these lines and others like them would never have been written, and the world would, in consequence, have been the poorer by so many priceless possessions. But what might be said 
of the many other works in which the influence of that element in the poet's make-up which we call neuropathic is not to be detected so readily? It is difficult, without appearing insolent, to touch with seemingly irreverent hands such a work as The Task, Cowper's greatest work, and it is but with the greatest diffidence that we venture to do so. Yet it does seem to us that the structure of the poem, the course of the argument through it, suggests, if examined with an eye to psycho-pathological peculiarities, something resembling flight of ideas, though it detracts not in the least either from its great charm nor from the wisdom that it breathes on every page. Had not this peculiarity been noted and pointed out by the poet himself, it would never have been referred to here; we would therefore cite his own words from a letter to Mr. Unwin, written under date of October 10, 1784, i. e., on completion of the poem but prior to its publication:

If the work cannot boast a regular plan (in which respect, however, I do not think it altogether indefensible), it may yet boast that the reflections are naturally suggested always by the preceding passage; and that, except the fifth book, which is rather of a political aspect, the whole has one tendency to discountenance the modern enthusiasm after a London life, and to recommend rural ease and leisure as friendly to the cause of piety and virtue.

It is interesting to note in this connection that Robert Southey, in commenting on the above-quoted remark of Cowper's concerning The Task, offers a defense against the possible criticism of lack of plan, without, however, questioning the validity of such a criticism, as follows:

If the world had not liked his poem, the world must have been worse than it is. But Cowper himself, perhaps, was not aware of what it was that supplied the place of plan, and with happier effect than the most skillful plan could have produced. There are no passages in a poet's works which are more carped at while he lives, than those wherein he speaks of himself; and if he has any readers after his death, there are none then which are pursued with greater interest. In The Task there is nothing which could be carped at on that score, even by a supercilious critic, and yet the reader feels that the poet is continually present; he becomes intimately acquainted with him, and this it is which gives to this delightful poem its unity and its peculiar charm.

The general conclusion seem inevitable that Cowper's works bear distinctly the reflection of his peculiar temperament, and in some instances they are the direct product of morbid moods and 
deranged imagination. Had Cowper not been insane he might still have written poetry, as others enjoying better mental health than he have done, but it would have been other poetry in that event.

It should not be necessary here to adduce evidence to prove that the case of William Cowper is properly to be included among those of intellectual efficiency of the highest order, as we have done. Should, however, any one be inclined to raise a question on this point, we would, in addition to simply pointing to the poet's works, direct attention to certain passages to be found in the letters that have been preserved in which he discusses some of his own works and which, it seems to us, exhibit "symptoms" of genius perhaps as unmistakable as those in the works themselves :

I little thought, when I was writing the history of John Gilpin, that he would appear in print; I intended to laugh, and to make two or three others laugh, of whom you were one. (This was addressed to Lady Austen.) But now all the world laugh, at least if they have the same relish for a tale ridiculous in itself, and quaintly told, as we have. Well, they do not always laugh so innocently, and at so small an expense, for in a world like this, abounding with subjects for satire, and with satirical wits to mark them, a laugh that hurts nobody has at least the grace of novelty to recommend it.

When his second volume of poems was about to appear from the press it was suggested to Cowper that a copy should be sent to Dr. Johnson, who then, as all know, occupied the leading position as a literary critic in England. Cowper agreed, " though I well know," said he, "that one of his pointed sarcasms, if he should happen to be displeased, would soon find its way into all companies and spoil the sale. Whatever faults I may be chargeable with as a poet, I cannot accuse myself of negligence. I never suffer a line to pass till I have made it as good as I can; and though my doctrine may offend this king of critics, he will not, I flatter myself, be disgusted by slovenly inaccuracy, either in the numbers, rhymes, or language. Let the rest take its chance."

In a letter to Mr. Unwin, under date of October 10, I784, speaking of The Task, which he had just completed, he writes:

What there is of a religious cast $I$ have thrown towards the end of it, for two reasons: First, that I might not revolt the reader at his entrance; and secondly, that my best impressions might be made last. Were I to write as many poems as Lope de Vega or Voltaire, not one of them would 
be without this tincture. If the world like it not, so much the worse for them. I make all the concessions I can, that I may please them, but I will not please them at the expense of conscience. My descriptions are all from nature; not one of them second-handed. My delineations of the heart are from my own experience; not one of them borrowed from books, or in the least degree conjectural. In my numbers, which I varied as much as I could ( for blank verse without variety of numbers is no better than bladder and string), I have imitated nobody, though sometimes perhaps there may be an apparent resemblance; because at the same time that I would not imitate, I have not affectedly differed.

Perhaps in this connection some would be interested in the beautiful and, of course, highly authoritative appreciation of Cowper written by Southey, if they have not already come across it in the literature:

William Cowper, the most popular poet of his generation, and the best of English letter writers, was born on the 15th of November (old style), 1731, in the Rectory, at Great Berkhamstead, Hartfordshire.

The place of his birth is remarkable in English history. The Mercian kings had a palace there; and it again became a royal residence under the first of the Plantagenets, who granted to the men and merchants thereof liberty to trade through all his lands of England, and Normandy, and Aquitain, and Anjou, without paying either custom or exaction; and that they should be quit of all servile works, and be exempt from all tolls, and enjoy the same liberties, laws, and customs, as in the times of Edward the Confessor; and that no market should be held within seven miles of the town. From Henry I.'s time, the honor and castle of Berkhamstead went with the earldom of Cornwall. Twice they were granted to unfortunate favorites; by Edward II. to Piers Galveston, and by Richard II. to Robert de Vere. Cicely, Duchess of York, and mother of the last of the Plantagenets, resided here during the latter years of her unhappy life; and from the time of her death, the honor of Berkhamstead has descended to the successive princes of Wales with the dukedom of Cornwall. Notable as these circumstances are, this little town will be more known in after ages as the birthplace of Cowper, than for its connection with so many historical personages who figured in the tragedies of old.

Of The Task Southey speaks as " that monument which, though not loftier than the pyramids, will more surely perpetuate its author's name than those eldest of human works have handed down the history of their founders."

For those who may attach greater importance to a generally accepted, conventional estimate of a poet's place in literature than to the impassioned utterances of another poet, we would quote 
from the article on William Cowper in the Encyclopædia Britannica :

Cowper is among the poets who are epoch-makers. He brought a new spirit into English verse, and redeemed it from the artificiality and the rhetoric of many of his predecessors. With him began the "enthusiasm of humanity" that was afterwards to become so marked in the poetry of Burns and Shelley, Wordsworth and Byron. ..... Added to this, one may note Cowper's distinction as a letter writer. He ranks among the half dozen greatest letter writers in the English language, and he was perhaps the only great letter writer with whom the felicity was due to the power of what he has seen rather than what he has read.

\section{(B) The Case of Julius Robert Mayer.}

There seems to be a widely current belief, though perhaps it is not often stated in so many words, that genius, when combined with insanity, is rather apt to be a manifestation of " the artistic temperament," and that the combination is generally to be found in poets, painters, sculptors, musical composers, and the like, and not in persons distinguished for stability of purpose and effort, calm judgment, continued attention to detail-qualities which are supposed to be more necessary in scientific work, in statesmanship, etc. That the qualities of literary or artistic genius are essentially very different from those of genius in other fields, that there is some radical contrast between the inspiration of poetic genius and that of scientific genius, is more than questionable. At any rate, the case of Julius Robert Mayer, the discoverer of the law of conservation of energy, would seem to leave no doubt of the fact that manic-depressive insanity may occur in connection with scientific as well as with artistic genius.

Mayer was born in Heilbronn on the 25th of November, 18I4. He was always of a sensitive, impulsive, violently reacting temperament, but showed no evidences of actual mental disorder until the age of 23 , and even then the very acute and transient mental upset which he had, and which will presently be described, gave rise to but a suspicion of insanity in the minds of those who observed it; however, in the light of the subsequent history of the case the real nature of this early upset is not so difficult to determine.

In the latter part of 1837 Mayer, at that time a student of medicine at Tübingen, was placed under arrest by the University 
authorities, as it appeared that he with some others was secretly maintaining the Corps Guestphalia, of which he had been one of the founders and which had ostensibly been dissolved by order of the University government. Following his incarceration he refused food, drank only water, complained of head congestion, and was treated twice, at his own request, by blood-letting. On the sixth day of his arrest, having shown no improvement, he was examined by a physician, who reported "that, considering all circumstances, Mayer could not be regarded as completely insane, but that he was nevertheless in a condition which might easily pass over into insanity"; accordingly it was decided that Mayer be removed to his home, there to remain during the remainder of his term of incarceration under "house-arrest," as his health demanded it.

In 1842 , that is to say, at the age of 28 years, Mayer published his first epoch-making work, "Bemerkungen über die Kräfte der unbelebten Natur"; in 1845 appeared his equally epoch-making "Die organische Bewegung in ihrem Zusammenhange mit dem Stoffwechsel"; and in 1848 followed his "Beiträge zur Dynamik des Himmels." The significance of these contributions from the standpoint of present-day physical science will be briefly discussed later on; suffice it to say here that at the time of their appearance the scientific world had evidently not grown up to an appreciation of their import, much less to an acceptance of the revolutionizing principle promulgated in them. Their first greeting was, therefore, either by crude criticism or, still worse, and for the most part, by complete indifference and neglect. In the meantime, however, new experimental data produced by Joule, Clausius, Thomson and others gradually prepared the way for the general recognition of the law of conservation of energy with all its consequences for the inorganic and organic worlds. Mayer's work seemed gradually to pass into oblivion or, if remembered, it was only for the purpose of disputing his claim to priority.

There can be no doubt that these unfortunate circumstances had a great deal to do with the subsequent recurrences of Mayer's illness. He, himself, years later, wrote as follows:

There lived within me a demand for recognition, and although I could try to conquer that feeling as one of sinful pride, yet it went beyond my strength to suppress within me my scientific conscience; the systematic 
AMERICAN JOURNAL OF INSANITY, VOL. LXXIII, No. 1. PLATE II.

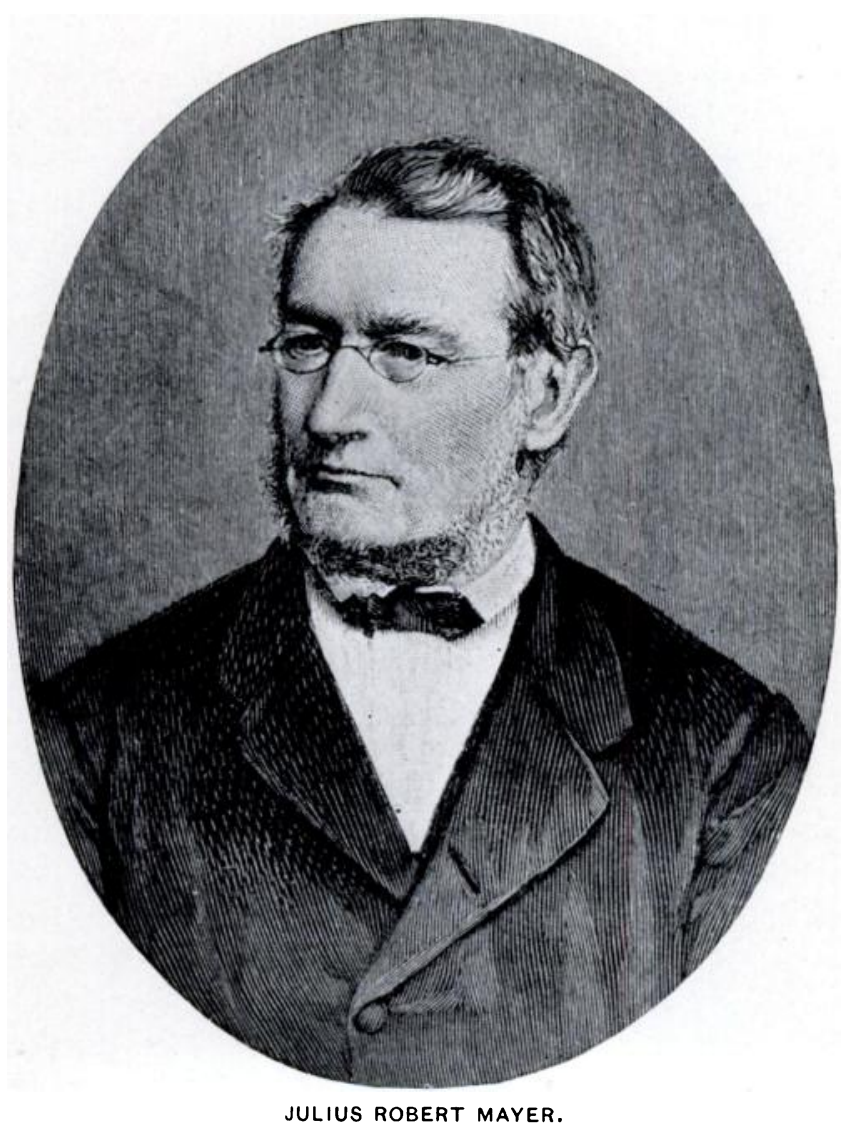


AMERICAN JOURNAL OF INSANITY, VOL. LXXIII, No. 1. PLATE III.

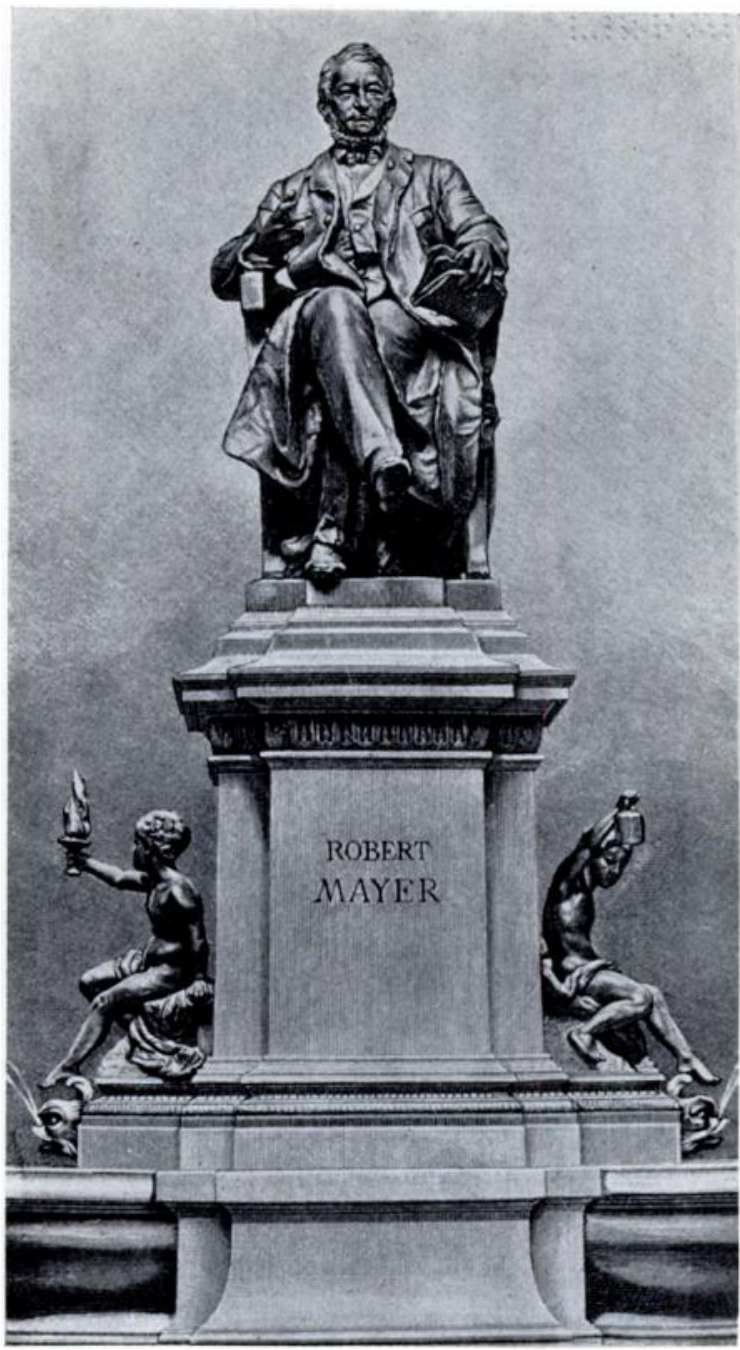

MAYER'S MONUMENT AT HEILBRONN. 
opposition which had been set against all my contentions, though the latter in the meantime proved to be entirely well founded, was bound to call forth in me from day to day a growing bitterness.

In 1849 there appeared in a popular magazine, namely, the supplement to the Allgemeine Zeitung, an attack on Mayer's work from the pen of a young Privatdozent at the University of Tübingen. Mayer was unable to prevail upon the editors to publish his answer to the criticisms. The whole incident, together with its tragic consequences, has subsequently been described by Mayer himself :

Since at that time the correctness in principle of the mechanical theory of heat was in competent circles no longer called in question, and in the "Comptes rendus" of the Academy of Paris only the question of priority as between me and Joule had come under discussion, that attack could only seem to me to rest upon falsehood due to crude and inexcusable ignorance. The gentleman from whom the attack proceeded was, however, regarded at the Cotta book publishing firm as a well esteemed personage, so that all my efforts to publish in the "Allgemeine Zeitung" a correction corresponding to the truth and demonstrating the soundness of my work were fruitless. ... . To this incident I have to attribute the fact that in the morning, on the 28th of May, I850, during the hot spring weather which prevailed at that time and which served to increase my state of irritation, having passed a sleepless night, in a sudden outbreak of an attack of delirium, while still undressed, I jumped out through the window, two stories ( 9 meters) down to the street, before the eyes of my wife who had been awake but a short time and whom the thing took entirely by surprise.

This resulted in an injury to his leg, with some permanent lameness. Whether other injuries were sustained is not clear from the available history ; it is stated, however, that he was confined to bed for a long time, that even his life was considered in danger, and that only after several months' treatment at Wildbad he regained his health sufficiently to be able to resume his work. There seems to be no record of his mental condition during all this time. $\mathrm{He}$ had, however, apparently recovered fully from the attack of delirium, to use his own expression, so that he was able but shortly after to publish his next and last great contribution to science, "Bemerkungen über das mechanische Aequivalent der Wärme."

In the fall of 185I, without apparent additional cause, Mayer again began to show signs of mental derangement. For a short time he underwent treatment in the private institution at Kennenburg, but on his discharge seemed but little better. One day in 
the early part of 1852 he called on his friend Lang, at that time the minister at Göppingen; he appeared greatly agitated, his talk was much confused and consisted mainly of ideas of great sinfulness. Lang tried to quiet him and advised him, as others had already done, to go to a newly established private asylum in the same town, to which Mayer agreed. In a few days he gained the conviction that treatment at that institution was not what he needed, and accordingly demanded his release, though his condition was still, to use his own expression, only to be described as desperate.

I had already bought my ticket at the railroad station, when the restlessness within me, my mental agony increased to the point of unconsciousness, and I have only a hazy, dream-like recollection of being put back into Dr. Landerer's cab and returned to his institution. At this point my memory fails; I lapsed into raging delirium; but my wife, who came hurriedly on the first notice, made Dr. Landerer to understand that he was dealing but with a case of brain inflammation in which not strait-jackets and ropes, but rather blood-lettings and ice-caps were indicated.

Mayer then remained at Dr. Landerer's institution for three months, and at the end of that time he was transferred to the state institution at Winnenthal, in which he spent 13 months more. Mayer's own account of his experience in these institutions is pathetic in the extreme. This account appears in a letter written to his friend, Heinrich Rohlfs, in 1877 , from which we quote:

It was in the early part of 1852 that I was persuaded by the director of the state institution for the insane, Hofrat von Zeller, whom I had long known personally and whom I had in my inexperience even regarded as a friend, to go to Göppingen where a Dr. Landerer, a nephew of Hof rat von Zeller, was just about to establish a private institution for the insane, the latter circumstance being, of course, unknown to me. I was the first one that came there and was as a "paying lunatic" a welcome prey to the lunatic director. I prefer to pass over the details of my so-called treatment, how, for instance, I was tortured to death in the restraining chair. After three months of such torture, on the night from the 3ist of July to the Ist of August, 1852, tightly laced in a strait-jacket, I was dragged to Winnenthal, where I arrived early in the morning, and was on that Sunday, by order of the Hofrat, immediately again strapped into a restraining chair which was there ready for me. In that institution I was for 13 months subjected to all imaginable somatic and psychic ill-treatment until I succeeded in forcing my liberation.

Following his discharge from the state institution at Winnenthal Mayer continued to have frequently recurring attacks of excitement, for most of which he was treated at home; however, one 
month in 1856 , one month in 1865 , and three months in 1871 he spent at the private asylum at Kennenburg, each time as a voluntary patient, under the care of Dr. Hussell and later of Dr. Mülberger.

During the early stages of the mental trouble that set in in $185 \mathrm{I}$ Mayer sought comfort from religion. Later, as he looked back upon this period, he said:

It is possible that the failure of all recognition, on which I had counted too soon, contributed its share to cool my enthusiasm for science; certain it is that at that time my interest for transcendental religious truths began to come out in me with an irresistible power..... With that vehement precipitation, that exclusiveness, from which I suffer as a constitutional failing, I threw myself at once into this field.

It would appear from the following letter, written to his friend Lang, then minister at Göppingen, under date of December 3I, $185 \mathrm{I}$, that for a time at least he found in religion the solace which he sought :

My earlier presentiment that the truths of natural science are, in relation to the Christian religion, somewhat like brooks and streams are to the ocean, has become a part of my living consciousness. Having succumbed in the attempt to sail beyond the streams before the high wind of impassioned zeal, it would have come to shipwreck with me in the past year, had not the grace of God, through you, opened the right way for me in the hardest hour of my life.

The self-accusations and ideas of sinfulness which Mayer expressed a few weeks later will be recalled in this connection, for there can be no doubt that both these, as well as the preceding beatific state, were but the first manifestations of the then beginning psychosis. It seems that shortly after he was taken to Dr. Landerer's institution at Göppingen Mayer, on emerging from the acute excitement, passed into a state of elation which he subsequently himself described, though evidently without full insight into its nature; of special interest from the psychiatric standpoint is the contrast presented by his changed religious attitude :

Having happily overcome this severe attack, which was also the last dangerous one, in spite of the treatment which was in part entirely senseless, and as my strength was re-established by sound sleep and good appetite-though I could not complain of being overfed-I felt like one who has recovered from a wild spree; I became joyfully conscious of the wonderful restoration of my mental health. In a short space of time a 
complete change occurred in me: not a trace more of visionary, pietistic sentimentality; I became a man again and, like Dr. Faust, feared neither death nor devil; the more Dr. Landerer and his helpers' helpers tortured me-and this occurred in a manner that would do honor to the old Spanish inquisition-the firmer grew my morbidly weak spirit.

Mayer himself had considerable insight into his mental trouble, always recognizing fully the abnormal nature of at least its more severe manifestations, but he never acquiesced in the idea that he was insane, preferring to speak of his attacks as "delirium" or "inflammation of the brain," and of the minor manifestations as mere temperamental traits quite within normal limits. As already stated, when he required treatment or seclusion he realized the fact, and several times applied for admission to the institution at Kennenburg as a voluntary patient. Perhaps the exact degree of insight which he had might best be judged from the following two letters written by him, the first under date of June $26,1865, i$. e., shortly after his discharge from the institution at Kennenburg, to Dr. Hussell, the physician-in-charge, and the second, dated at Kennenburg, November 3, 1871 , i. e., when about to be discharged, to his wife.

\section{Esteemed Colleague!}

I came very near accepting your kind invitation to visit Kennenburg, intending to deliver personally the amount of the bill which I now enclose herewith. You may judge from this surely that I hold your blessed institution in grateful remembrance, and also that I realize very well that the disagreeable mood, in which I often was while there, and from which I do not always feel myself free even here, was but the result of my mental disorder; and I do not cease to admire and to praise the forbearing patience with which you then treated me.

Dear Wife!

I wish to utilize the peace of solitude to pass the time with you and to thank you cordially for your dear letter of the 3oth of last month together with the enclosure. When the fall is over and your dear guests have gone back again to Mannheim, things will surely be very quiet with you. I can see that from afar you have viewed everything more calmly and more correctly and I submit, as you see, to your instructions, though I cling to the hope which you gave me when we were together last, which occasion it is such a pleasure for me to recall. What pleases least both you and me, my vehement temperament, shall surely be held in check by even greater self-control. Will this always succeed? I shall take all pains, for to know that the wife is contented and happy is the highest pride and the highest task of the man; yet, in the imperfection of human 
things, I aiso hope for your indulgence and forgiveness, above all for things which have passed and many of which I no longer even remember.

It seems that no other records of psychiatric import are to be found concerning Mayer's case. But Weyrauch, his principal biographer, obtained from the surviving friends of Mayer their personal reminiscences concerning him. ${ }^{2}$ Mayer's opinion concerning Hofrat von Zeller is sufficiently clear from some of his letters which we have quoted. Lang relates that while Mayer was at the asylum at Winnenthal, on the occasion of an official visit by state authorities, he called to von Zeller in the presence of all the dignitaries, "Der einzige Narr in diesem Hause sind Sie!" Von Zeller, on the other hand, told Lang that in all his 40 years' experience he had not had a more difficult patient to deal with. The treatment which Mayer received at Göppingen and at Winnenthal was but like that in general vogue almost everywhere in those days, though to-day we would agree with Mayer's condemnation of it in every respect: the fact is, that in the treatment of mental disturbances, as in the field of natural science, his great mind, his unerring instincts, placed him in advance of his time. To add to the hopeless mess, it seems but too certain that Mayer's claim that he had discovered a natural law of the highest and most far-reaching importance, having as yet received no authoritative recognition, was regarded by von Zeller and others as nothing but a delusion of grandeur; von Zeller, in fact, told him, "Sie haben die Quadratur des Zirkels gesucht." It seems even that for many months Mayer was kept in the asylum when there was no other indication for his detention than this "delusion of grandeur."

The last circumstance has led some of Mayer's biographers to doubt the fact of his having been insane at any time, but it seems to us that the testimony of eye-witnesses leaves no room for such doubt.

Dr. Hussell, who was the director of the institution at Kennenburg when Mayer was there in 1865 , wrote as follows :

That his ailment which was peculiar and, I repeat, difficult to form a judgment of, belonged to the domain of psychiatry was and is not to be doubted. In relatively calm moments-I say relatively because a lasting inner calm was hardly to be observed, for even during the periods of depression which either preceded or followed the states of exaltation there was to be noticed a restless vibration,-Dr. Mayer showed no striking deviation from normal thinking. 
Dr. Mülberger, of the same institution, under whose care Mayer was in 1871 , wrote as follows:

The states of exaltation proper in Mayer's illness recurred but seldom during his stay at Kennenburg. During the four months which he spent there in 1871 , temporary seclusion in a cell was required perhaps three, at most four times, and fortunately these states did not last long; on the second day the excitement would begin to subside, and a few days later, as a rule, mental balance would be tolerably reestablished. Mayer understood his own case very accurately. I believe that, when his condition made necessary his seclusion from the outer world, there was not a single time when he had to be reminded of it.

Gustav Rumelin, who had been Mayer's playmate and friend from boyhood, and who later was member of the Parliament at Frankfort and Chancellor of the University of Tübingen, recalled Mayer's case as follows :

He never had delusions and fixed ideas, properly so called in a strict sense, so as to lose correct consciousness of self, realization of his surroundings, the normal meaning of sense impressions; also the logical coherence of his actions and speech always remained still recognizable. Yet his condition was capable of reaching a point where the most insignificant occasions or impressions which seemed to him to bear anything of insult, or threat, or vexation would arouse in him the most boundless excitement ; where he would see, with an astonishing gift of combination, in ordinary happenings, connections and motives which were purely of his own imagining and which would lead him to turn his suspicions and misinterpretations against his closest relatives and friends attributing to them the most incredible things. At such times he would run for hours or for halfdays or half-nights through all the rooms of the house in a restless manner, talked or shouted almost without interruption, at times words of indistinguishable meaning, no longer kept within the usual moderate limits of alcoholic indulgence, and thus aggravated his condition to the point of being wholly unbearable to himself or those about him. Often the calm and recovery of self after such manifestations would set in of itself; at other times he would make up his mind, or allow his relatives and friends to persuade him, to seek treatment in an institution. He never was taken to one against his will, which would anyway have been quite impracticable with his disposition.

Mayer's son, Dr. Paul Mayer, who is a physician, stated that his father's mental disorder was in the emotional and not in the intellectual sphere:

The latter remained clear up to the last moments, and none of us had ever noticed anything about him that would prove the existence of hallucinations or even illusions. 
We come now to the question whether Mayer's mental efficiency was in any essential way connected with his neuropathic constitution. In this particular connection this question presents more than ordinary, perhaps insurmountable, difficulty. A writer of poems or of novels has unlimited freedom of choice of subject or style, and any peculiarity that there may be in the working of his mind has every opportunity of being revealed more or less clearly and more or less constantly in his works; but such is not the case with one who writes on scientific subjects : if in him any connection exists between mental peculiarity and fruitful activity, any evidence for it may be expected to be found only in data which bear but an indirect bearing on the question. In Mayer's case, unfortunately, data of any kind pertinent in this connection are scarce, so that a sure conclusion is hardly to be reached. What evidence there is, however, is somewhat suggestive.

Those who knew Mayer intimately gave, according to his biographers, unanimous testimony as to his extraordinary determination, his " unbending will," to quote the characterization most frequently employed. That this feature had much to do with his intellectual efficiency no one is likely to dispute, but that it was a function of the neuropathic element in his make-up is far from being equally certain, though to us it seems not improbable. It is interesting to recall in this connection that this "unbending will" was looked upon as the cause of the greatest difficulty encountered in the treatment of his case, and von Zeller even told Mayer once, "Wir müssen Ihnen einen andern Willen schaffen." And it is still more interesting to note that Mayer himself ascribed to the special intensity of his will not only the success of his scientific work, but also perhaps the most significant manifestation of his mental disorder, namely, the remarkable religious trend of $185 \mathrm{I}$ and 1852 , together with the ideas of sinfulness, etc., which vanished in a few months :

With that vehement precipitation, that exclusiveness, from which I suffer as a constitutional failing, I threw myself at once into this field.

There is still to be mentioned, as having a possible bearing on our question, the lightning-like suddenness with which Mayer's principal idea occurred to him while on a sea-voyage in the temporary capacity of ship surgeon, and the peculiar period of inspiration which followed and during which the subsequent development 
of that idea in his mind took place. At that time, namely, about the middle of July, 1840 , Mayer was but 26 years of age. He was in no way equipped to consider in a competent way even simple problems of natural science, and much less a problem presenting the greatest theoretical difficulties. He had done rather poorly at school, his preliminary education was most ordinary; he then studied medicine, and it so happened by reason of special conditions that he received practically no instruction in physics, in which, moreover, he appeared to take no special interest: it is clear that not to any special preparedness can Mayer's discovery be attributed. As the immediate excitants of his great idea are to be mentioned two most commonplace occurrences : a remark of an old pilot to the effect that after a severe storm the sea is always noticeably warmer than before; and an observation which Mayer himself had made and which, he found later, was corroborated by the experience of others, that in the warm climate of the tropics the venous blood which escapes in blood-letting is almost as bright as arterial blood, showing, of course, that there is less active oxidation; his trend of thought soon led him to compare animal heat and muscular work as the results of the same chemical process, i.e., oxidation, and as being therefore convertible into one another. This happened while the ship was in East Indian waters, and although Mayer could have landed to see the tropical country, which had been the object of his trip, he did not do so, later giving the following explanation in a letter to his classmate Griesinger, who afterwards became the well-known leader in psychiatry:

I stuck to the subject with so much preference, and many would laugh at me for it, that I made but little inquiry about that distant part of the world, but found it most to my liking to remain on board where I could work without interruption and where in many an hour I felt as though inspired, a feeling the like of which I do not recall having ever had either before or since. A number of thought-flashes that passed through my mind were at once eagerly followed up and in their turn led to new subjects.

Mayer's first formulation of his discovery in a paper entitled "Uber die quantitative und qualitative Bestimmung der Kräfte" was so imperfect and so full of crude errors that Poggendorff, to whom he had sent his paper, would not publish it in his Annalen der Physik und Chemie. In a few months, however, he had so thoroughly equipped himself with the necessary knowledge of 
mathematics and physics that he was ready with his greatest work, "Bemerkungen über die Kräfte der unbelebten Natur," of which Ostwald says:

In the content of the classical work that was then written the future has in fact found nothing important to change. Only the experimental values employed for the specific heat of air, for the correctness of which Mayer was, of course, not responsible, would have to be corrected.

The papers which followed, and the titles of which have already been given, contained a thorough elaboration of the great principle and a discussion of its significance for biology, for astronomy, for all natural science. As stated in the early part of this section, the last contribution of importance appeared in the early part of $185 \mathrm{I}$, when Mayer's creative power seems to have become permanently exhausted, i. e., at the end of a period of most extraordinary inspiration and activity lasting but ten or eleven years. Prior to this period Mayer had given no promise of great possibilities; following it, every attempt that he made to resume his scientific labors showed but the hopelessness of his ever again attaining to his former heights.

Whatever may be said of the nature of the relationship existing between Mayer's intellectual efficiency and his insanity, it is certain that the former was not a characteristic feature of his mind in its average condition, but that it was manifest only during a small fraction of his lifetime, namely, during a period of hyperfunction as far beyond the normal level for him individually as for the average person, a period very clearly circumscribed in his life, its onset as well as its termination being sudden and without premonition.

Like the case of Cowper, that of Mayer was selected for the purposes of the present study partly for the reason that the propriety of including it among those of intellectual efficiency of the highest order seemed not likely to be questioned. It seems, however, that there are still to be heard occasional echoes of the old dispute about priority. It may, therefore, be necessary to state that, although at first for a number of years recognition was withheld, the tide began to turn in the latter part of 1858 , and from that time until his death in 1878 Mayer was at various times the recipient of great scientific honors in the shape of election to honorary membership in scientific societies, honorary scientific 
degrees, prizes, medals, etc. In I87 I Tyndall wrote to Mayer as follows:

It is one of the greatest pleasures of my life to announce to you that this day the Council of the Royal Society has awarded you the highest honor which it is in the power of the Society to bestow, namely, the Copley medal.

This letter had to be forwarded to the asylum at Kennenburg, where Mayer was at that time!

Later Tyndall wrote as follows: *

Though this (first) paper contains but the germ of his further labors, I think it may be safely assumed that, as regards the mechanical theory of heat, this obscure Heilbronn physician, in the year 1842, was in advance of all the scientific men of the time.

And with reference to Mayer's second paper he wrote, similarly:

As regards these questions of weightiest import to the science of physiology, Dr. Mayer, in 1845, was assuredly far in advance of all living men.

Also Ostwald, in closing his brief biographical sketch of Mayer, speaks of him as "the first bearer of the greatest discovery that had been reserved for the nineteenth century."

\section{(C) The Case of Gustave Flaubert.}

Gustave Flaubert was born at Rouen December 12, I821. Psychically he presented some unusual traits which seem to have determined the peculiar method and results of his literary labors and which were in some way associated with epileptic attacks.

That we are dealing here with a case of genuine epilepsy, recognized as such by competent observers, including Flaubert himself, may be judged from the following account by du Camp and from the remarks of Mme. Commanville (Flaubert's niece) and of Flaubert :

In the month of October, 1843 , he had been at Pont-Audemer and his brother Achille had gone there after him. One evening they left there together in a carriage driven by Gustave himself. The night was dark; in the vicinity of Bourg-Achard, just as a man with a cart passed on the left side of the carriage while on the right in the distance the light of an isolated inn became visible, Gustave was stricken and fell. His brother bled him on the spot, hoping, though not fully believing, that he had witnessed but an accident which would not repeat itself. Other nervous attacks supervened; he had four during the fortnight which followed. 
AMERICAN JOURNAL OF INSANITY, VOL. LXXIII, No. 1. PLATE IV.

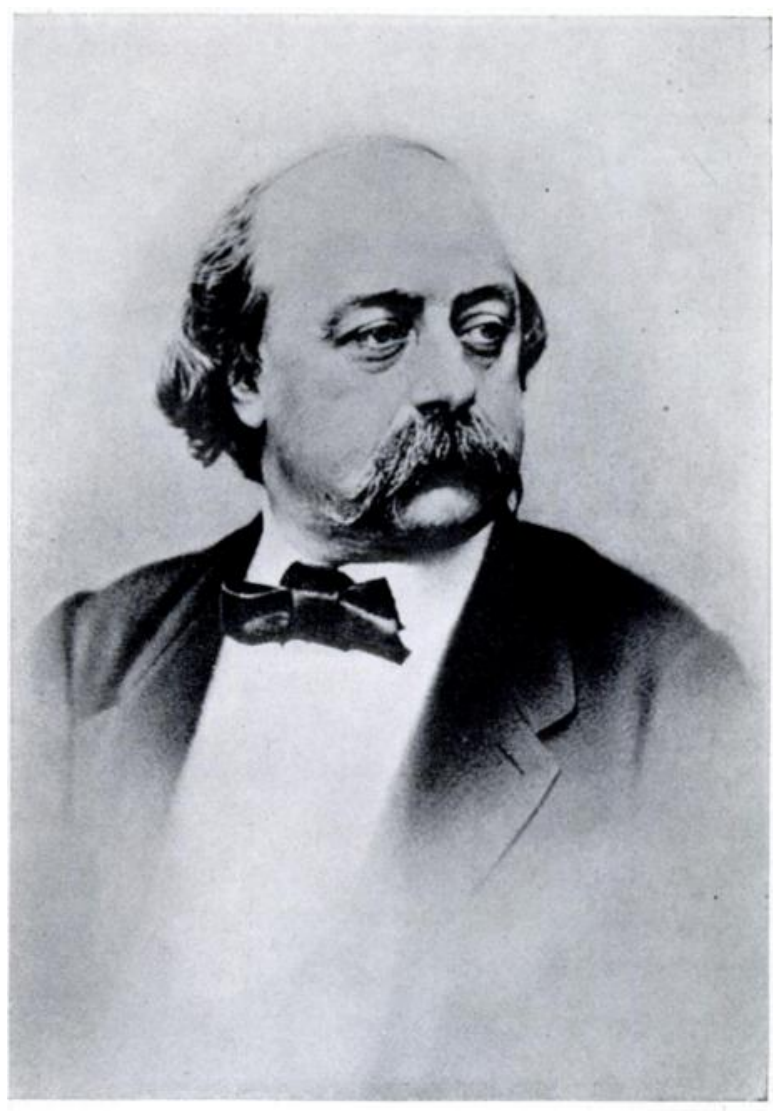

gustave flaubert. 
Flaubert's father (who was surgeon-in-chief of the Hotel-Dieu Hospital) was in despair and, as unfortunately he belonged to the school of Broussais, he could see no other remedy than that of extreme blood-letting and thus further aggravated the nervous state which was already very formidable. One day, as he was about to bleed Gustave and as the blood failed to appear at the vein of the arm, he ordered hot water to be poured on the hand; in the general confusion it was not noticed that the water was almost boiling, and the unfortunate patient sustained a burn of the second degree from which he suffered cruelly. "Excess of plethora, too much force, too much vigor," said Flaubert's father, and the patient was forbidden liquors, wine, coffee, dark meats, and tobacco. He was stuffed with valerian, indigo, castoreum. He swallowed the drugs with resignation, ate white meats, gave up smoking, drank decoction of orange leaves, and would say, smiling, "This is not so good as Sauterne." He took out of his father's library the works on nervous diseases and read them; at the end of this reading he said to me, "I am lost."

Quite often, powerless and dismayed, I assisted at these attacks, which were formidable. They always came on in the same manner and were preceded by the same phenomena. All of a sudden, without apparent cause, Gustave would raise his head and become very pale: he felt the aura, that mysterious breath that is felt on the face like the flight of a spirit; his expression would become filled with anguish and he would shrug his shoulders with a gesture of heartrending discouragement; he would say, "I see a flame with my left eye"; then, a few minutes later, "I see a flame with my right eye, everything seems golden in color." This peculiar state sometimes lasted several minutes. At this moment, it was noticeable, he was still in hopes it would end with the warning; but then his face would become still paler and assume an expression of despair; quickly he walked, he ran toward his couch and stretched himself out on it, gloomy, hopeless, as though he had gone down alive into his grave; then he would cry out, "I hold the reins! See the man with the cart! I hear the bells! Ah! I see the light of the inn!" Then he would emit a cry the heartbreaking sound of which still vibrates in my ear, and the convulsion followed.

These paroxysms, which caused the whole body to tremble were invariably followed by profound sleep and by a general soreness which lasted several days. ....

I have never heard him utter the true name of his illness; he would say, "my attacks of nerves," and that was all. Did he have the first seizure on that night of his journey from Pont-Audemer to Rouen? He did not believe that; he recalled that three months before, in Paris, he awoke in a state of unwonted lassitude which, without apparent cause, persisted a whole week. He felt convinced that his first seizure occurred during sleep, and he probably had reason, as his nocturnal attacks were quite frequent. 
Mme. Commanville wrote:

His disposition was even and cheerful with frequent droll spells, yet in the depth of his nature there was a vague sadness, a sort of uneasiness; physically he was robust, inclined to many strong enjoyments, but his soul, aspiring toward a non-existent ideal, suffered constantly from not finding it in anything. This showed itself in the merest trifles; he wished not to feel life, for, seeker after the exquisite without compromise, he grew to feel sensation itself almost always as a pain. This undoubtedly had to do with that sensitiveness of the nervous system that the violent commotions of a malady, of which he had a number of attacks, especially in his youth, had brought to the keenest point. But it also was the result of his great love of the ideal. This nervous malady darkened his whole life; it was a fear that dampened the brightest days; yet it did not affect his robust health, and the incessant and vigorous labor of his brain continued without interruption.

In 1852 , in a letter to Mme. X., Flaubert wrote:

Without the love of form I should perhaps have been a grand mystic; add to this my attacks of nerves, which are nothing but involuntary declivities of ideas and images; at such times the psychic element passes above me and consciousness disappears together with the sensation of life. I am sure that I know what it is to die; I have often distinctly felt my soul as it left me, as one feels the blood pouring through the opening at blood-letting. . . . . Fhat devil of a book (Louis Lambert by Balzac) set me dreaming all night about Alfred (Le Poitevain). .... Was it Louis Lambert that summoned Alfred this night? Eight months ago I dreamed of lions, and at the moment of my waking a barge carrying a menagery passed under my windows. How near one sometimes feels to madness, I especially. You know my influence on madmen and how they love me! .... I shall make use of all this by introducing it into a book, the metaphysical novel with apparitions of which I spoke to you; but as I am afraid of the subject from the health point of view, I must wait."

Aside from the vague hints contained in the above quotations, is there any evidence that the neuropathic elements in Flaubert's personality were in any measure a factor of the remarkable quality of his work? This question is to-day hardly to be answered definitely: psychiatry has not yet formulated a clear description of epileptic personality, the various manifestations of defectiveness shown by institutional cases having been hitherto dwelt upon almost exclusively. Yet even institutional cases of epilepsy, if not associated with gross defectiveness or dementia, of ten strike one by a mental trait developed to an unusual degree and consisting in 
a meticulous attention to detail in observation, in labor, and in expression.

However this may be, the generally accepted appraisals of Flaubert as a writer emphasize his unrivalled precision of style and minutest faithfulness in portraiture of life. How was this achieved? By untiring attention to detail; for we find that his spontaneous flow of language was by no means so precise as the finished product, that " the language of his letters is copious, easy, almost purposely careless and trivial, disconnected, overloaded, violent, emphatic and unbridled." " De Maupassant gives the following description of the way Flaubert worked:

Down there, at Croisset, in his large study with five windows, he moaned night and day over his work. Without compromise, without remission, without pleasures or distractions, under great strain of mind, he progressed with discouraging slowness, discovering each day new reading to be done, new researches to be undertaken. And the phrase so tormented him, the phrase so concise, so exact, yet with color, which had to comprise a volume in two lines, all the thoughts of a savant in a paragraph. He would take up together a number of ideas of the same nature and, like a chemist preparing an elixir, he would dissolve them, reject those that are merely accessory, simplify the principal ones, and out of his formidable crucible would come forth absolute formulas containing in $\mathbf{5 0}$ words a whole system of philosophy. .... He would take up his sheet of paper and raise it to his line of sight, then leaning on his elbow, declaimed it in a slow, incisive voice. He listened for the rhythm of his prose, stopping as if to catch an elusive sonority, combining tones, avoiding alliterations and conscientiously placing his commas like halts on a long road.

Flaubert himself said:

A phrase can live only when it corresponds to all the necessities of respiration. I know it to be good when it can be read aloud. . . . Badly written sentences do not stand this test; they weigh on your chest, hinder the beating of your heart, and thus find themselves outside the conditions of life.

The manner in which the posthumously published unfinished novel, Bouvard et Pécuchet, was produced is, perhaps, of the greatest interest in this connection. We quote again from de Maupassant :

Gustave Flaubert did not write Bouvard et Pécuchet at one stroke. One might say that half of his life passed in meditating this book and that he devoted the last six years of his life to the carrying out of this feat of strength. An insatiable reader, indefatigable searcher, he piled up 
material without rest. Finally, one day, he set himself at work, though dismayed by the enormity of his task. "One must be insane, who would undertake such a book," he often said. It required above all a superhuman patience and an ineradicable will.

The plot is simple enough. Bouvard and Pécuchet, two copying clerks, having unexpectedly inherited a fortune at the age of 5o, decide to devote themselves to more interesting pursuits. They try agriculture, indulge in love affairs, and are duped, ruined, and disappointed; owing to their fondness for novelties they are looked upon unfavorably by provincial people; they try to become intellectual by reading books on medicine, history, philosophy, philology, mathematics, astronomy, physiology, and a great deal more, and end up by becoming completely disappointed and returning to their clerkships.

When Bouvard and Pécuchet, disgusted with everything, returned to their copying, they opened the books which they had read, and taking up again the natural order of their studies, transcribed minutely the passages chosen by them in the works which had attracted them. Then began a frightful series of ineptitudes, ignorances, flagrant and monstrous contradictions, enormous errors, shameful assertions, of inconceivable falterings of the greatest minds, of the vastest intellects. Whoever has written on any subject has at times said something stupid. These stupid things Flaubert has infallibly sought out and collected; and, bringing them together, he made of them a formidable pile which will disconcert all belief and all assertion.

This collection of human stupidities made up a mountain of notes which remained too scattered, too much mixed up, to be ever published in full.

A few quotations will illustrate the range and nature of these notes.

"This people (the ancient Greeks), so brilliant, has founded nothing, established nothing that is durable, and has left behind nothing but traces of crimes and disasters, books and statues. It always lacked reason." (Lamennais. Essai sur lindifférence. Vol. IV, p. 171.)

"The study of mathematics, by curbing sensibility and imagination, sometimes causes explosions of terrible passion." (Dupanloup. Education intellectuelle. p. 417.)

"Superstition is an advance work of religion which should not be destroyed." (De Maistre. Soirées de Saint-Pétersbourg. p. 234.)

"My ladies! In the march of Christian society, upon the railway of the world, woman is the drop of water whose magnetic influence, vivified and purified by the fire of the Holy Ghost, adds its movement too, under its beneficent impulsion, to the social procession; it runs upon the path of progress, advancing toward the eternal doctrines. But when, instead of furnishing the divinely blessed drop of water, woman brings the stone of derailment, frightful catastrophes are the result." (Mgr. Mermillod. De la vie surnaturelle dans les âmes.)

"I should find it bad for a girl of little wisdom to live with a man before marriage." (Ponsard. Traduction d'Homère.) 
"The wealth of a country is dependent on its general prosperity." (Louis-Napoléon. Cited in Rive gauche, March 12, 1865.)

"The inundations of the Loire are due to excesses of the press and to non-observance of Sunday." (L'évèque de Metz. Mandement. December, 1846.)

"The women in Egypt prostituted themselves publicly with crocodiles." (Proudhon. De la célébration du dimanche. 1850.)

"I have several times heard deplored the blindness of counsel of François I., who rebuffed Christopher Columbus proposing the expedition to India." (Montesquieu. Esprit des Lois. Vol. XXI, Ch. XXII.) François I. ascended the throne in 1515 . Columbus died in 1506 .

"It requires greater genius to be a boatman on the Rhone than to produce the Orientales." (Proudhon.)

"No one doubts that extraordinary men, of whatever sort, owe no part of their success to any endowment of their organization with superior qualities." (Damiron. Cours de philosophie. Vol. II, p. 35.)

"As soon as a Frenchman has passed the frontier he enters upon foreign territory." (L. Havin. Courrier du Dimanche.)

"The melon has been divided by nature into slices in order that it may be eaten by a family; the pumpkin, being larger, may be eaten with the neighbors." (Bernardin de Saint-Pierre. Etudes de la nature.)

There is an equivalent of about three volumes of such notes. Flaubert's aptitude in discovering this sort of stupidities was astonishing. The following instance is characteristic. In reading a discourse delivered at the French Academy he stopped at the following passage, immediately writing down his note of comment:

"Does the comedy of Molière teach us anything about the great events of the period of Louis XIV? Does it tell us a word about the errors, the weaknesses, or the faults of the great king? Does it tell us about the revocation of the Edict of Nantes?"

He wrote under this quotation: "Revocation of the Edict of Nantes, 1685. Death of Molière, 1673." How could it happen that none of the academicians, who met in committee to listen to the reading of this discourse before it was delivered in public, made this simple comparison of dates?

Outside of France Flaubert's works are not so well known as they should be. The question may be raised by some readers whether it is proper to include his case among instances of intellectual efficiency of the highest order.

The above account of Flaubert's personality and work presents, it seems to us, unmistakable "symptoms" of greatness. More such symptoms may be perceived in the following extracts from his letters :

You complain that events are not varied; that is a realistic complaint, and, moreover, how do you know? The question is of their closer observa- 
tion. Have you ever believed in the existence of things? Is not all an illusion? There are no truths other than accounts, that is to say, the manner in which we perceive objects.

Bovary is an unheard-of feat, of which I alone am conscious: the subjects, the characters, the effects, etc., etc., all is outside myself. . . . I I think that that is as it should be. What you write is not for yourself but for others; art has nothing to do with the artist. If he does not like red, green, or yellow, all the worse for him. All colors are beautiful. They have to be painted.

You will look with pity upon the custom of celebrating one's own self. It may succeed once, in a shout; but whatever may have been the lyrism of Byron, for instance, see how crushed it is by the superhuman impersonality of Shakespeare! Do we even know whether he was merry or sad? The artist must manage so as to lead posterity to think that he never lived at all. The less I can form an idea of him the greater he seems to me. I can imagine nothing as to the person of Homer or of Rabelais, and, when I think of Michael-Angelo, I see. the back view only of an old man of colossal stature working at his sculpture by night with torchlight.

Personal sentimentality will later on cause a great deal of contemporary literature to be considered as puerile and rather silly. What feelings! what tenderness! what tears! There never were so many good souls.

Speaking of Flaubert's first novel, Henry James says :

The perfection of "Madame Bovary" is one of the commonplaces of criticism, the position of it one of the highest a man of letters dare dream of, the possession of it one of the glories of France.

The general appraisal of Flaubert as a writer is well voiced in the Encyclopædia Britannica:

That he was one of the greatest writers who ever lived in France is now commonly admitted, and his greatness principally depends upon the extraordinary vigor and exactitude of his style. Less perhaps than any other writer, not of France, but of modern Europe, Flaubert yields admission to the inexact, the abstract, the vaguely inapt expression which is the bane of ordinary methods of composition. He never allowed a cliché to pass him, never indulgently or wearily went on, leaving behind him a phrase which "almost" expressed his meaning. . . . . The publication of Madame Bovary in 1857 had been followed by more scandal than admiration; it was not understood at first that this novel was the beginning of a new thing, the scrupulously truthful portraiture of life. . . . . It has been perceived that he was not merely realistic, but real; that his clairvoyance was almost boundless; that he saw certain phenomena more clearly than the best of observers had done. Flaubert is a writer who must always appeal more to other authors than to the world at large, because the art of writing, 
the indefatigable pursuit of perfect expression, were always before him, and because he hated the lax felicities of improvisation as a disloyalty to the most sacred procedures of the literary artist.

To summarize: The evidence presented by the cases of William Cowper, Julius Robert Mayer and Gustave Flaubert shows clearly that grave neuropathic conditions, particularly manic-depressive psychoses and epilepsy, are not incompatible with the highest degree of intellectual efficiency; it seems even that in these cases the morbid elements of personality have been among the factors of the high quality of the intellectual products.

Other such cases are to be found among the great men of every land; and if milder psychoses and neuroses should be included, then the percentage of neuropathic persons among them would undoubtedly be found relatively high, though still by no means high enough to render the neuropathic genius anything but an exception to the general rule. There are too many who must be counted as normal by the strictest standards to permit the conclusion, which some have drawn, that a deep and essential relationship exists in general between genius and madness.

For eugenics, the cases described in this paper, and others that are met with almost daily in psychiatric practice, obviously hold important consequences : the existence of a neuropathic condition, established by medical diagnosis, can no longer be regarded as sufficient grounds for the advocacy of negative eugenic measures; not insanity, not epilepsy, as such, but mental disablement, is the proper concern of eugenics.

\section{REFERENCES.}

I. Robert Southey: The Life of William Cowper. Boston, 1839 .

2. Jacob J. Weyrauch: Kleinere Schriften und Briefe von Robert Mayer. Stuttgart, 1893.

3. Wilhelm Ostwald: Grosse Männer. Vol. I. Leipzig, 1910.

4. John Tyndall: The Copley Medalist of 1871. In Fragments of Science. Vol. I. New York, Ig0r.

5. Maxime du Camp: Souvenirs Littéraires. Vol. I, pp. I6r et seq. Paris, I892.

6. Caroline Commanville: Souvenirs intimes. In Gustave Flaubert's Correspondance. Paris, 1889.

7. Gustave Flaubert: Correspondance. Paris, I889.

8. Émile Faguet: Flaubert. English translation by Mrs. R. L. Devonshire. Boston and New York, 1914.

9. Guy de Maupassant: Étude sur Gustave Flaubert. In Oeuvres complètes de Gustave Flaubert. Vol. VII. Paris, 1885. 